\title{
"Corporate hedging theories and usage of foreign currency loans: a logit model approach"
}

\begin{tabular}{|c|c|}
\hline AUTHORS & $\begin{array}{l}\text { Mahadevan Sriram (D https://orcid.org/0000-0002-7866-7687 } \\
\text { Srilakshminarayana Gali (D https://orcid.org/0000-0002-2680-0538 }\end{array}$ \\
\hline ARTICLE INFO & $\begin{array}{l}\text { Mahadevan Sriram and Srilakshminarayana Gali (2020). Corporate hedging } \\
\text { theories and usage of foreign currency loans: a logit model approach. Investment } \\
\text { Management and Financial Innovations, 17(4), 367-377. } \\
\text { doi:10.21511/imfi.17(4).2020.31 }\end{array}$ \\
\hline DOI & http://dx.doi.org/10.21511/imfi.17(4).2020.31 \\
\hline RELEASED ON & Friday, 18 December 2020 \\
\hline RECEIVED ON & Saturday, 03 October 2020 \\
\hline ACCEPTED ON & Monday, 07 December 2020 \\
\hline LICENSE & $\begin{array}{l}(c)) \text { EY } \\
\text { This work is licensed under a Creative Commons Attribution } 4.0 \text { International } \\
\text { License }\end{array}$ \\
\hline JOURNAL & "Investment Management and Financial Innovations" \\
\hline ISSN PRINT & $1810-4967$ \\
\hline ISSN ONLINE & $1812-9358$ \\
\hline PUBLISHER & LLC "Consulting Publishing Company "Business Perspectives" \\
\hline FOUNDER & LLC "Consulting Publishing Company "Business Perspectives" \\
\hline$\sigma^{0}$ & $\begin{array}{l}\text { ニニ } \\
\text { 三: }\end{array}$ \\
\hline NUMBER OF REFERENCES & NUMBER OF FIGURES \\
\hline 32 & 7 \\
\hline
\end{tabular}

(C) The author(s) 2021. This publication is an open access article. 


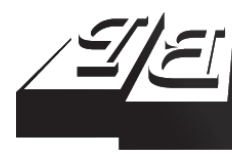

BUSINESS PERSPECTIVES

(O)

LLC "CPC "Business Perspectives" Hryhorii Skovoroda lane, 10 Sumy, 40022, Ukraine www.businessperspectives.org
Received on: $3^{\text {rd }}$ of October, 2020 Accepted on: $7^{\text {th }}$ of December, 2020 Published on: $18^{\text {th }}$ of December, 2020

(C) Mahadevan Sriram,

Srilakshminarayana Gali, 2020

Mahadevan Sriram, Ph.D, Dr., Associate Professor (Finance), SDM Institute for Management Development, Mysuru, Karnataka, India. (Corresponding author)

Srilakshminarayana Gali, Ph.D, Dr., Associate Professor (Quantitative Methods), SDM Institute for Management Development, Mysuru, Karnataka, India.

\section{CORPORATE HEDGING THEORIES AND USAGE OF FOREIGN CURRENCY LOANS: A LOGIT MODEL APPROACH}

\begin{abstract}
The present study has attempted to discuss the association between corporate hedging theories and the usage of foreign currency loans by companies listed in India. A total of 349 non-financial companies were selected, and the data for the financial year ending 31st March, 2018 were considered for the analysis. The descriptive statistics indicate that $55 \%$ of the sample companies had borrowed funds in foreign currency. The companies were highly levered and maintained adequate short-term assets to honor shortterm obligations. A logit model was employed for analyzing the cross-sectional data. The dependent variable being binary (' 0 ' for non-user of foreign currency loans and ' 1 ' for foreign currency loan user), the study found the variable 'industry type' to have a significant association with usage of foreign currency loans. Companies from the manufacturing sector were likely to use foreign currency loans than companies from the services sector. Debt to net worth, export to sales, revenue (log of revenue) were the variables that significantly influenced the likelihood of companies raising foreign currency loans. Interest coverage ratio had a negative influence on the likelihood of companies opting for foreign currency loans. Hosmer and Lemeshow test showed that the model is a good fit indicating $73 \%$ accuracy in predicting the users of foreign currency loans as 'foreign currency loan users'. Theories such as financial distress, size, and extent of international operations explain why companies raise foreign currency loans.
\end{abstract}

Keywords

logit model, debt to net worth, export to sales, revenue, financial distress, size and international operations, interest coverage ratio, India

\section{JEL Classification G32, G39, G30}

\section{INTRODUCTION}

The foreign exchange rate exposure of non-financial companies has been extensively researched, and numerous studies have discussed how companies are sensitive to exchange rate volatility. The continuous movement in foreign exchange rates indicates that companies operating globally are exposed to exchange rate risk vagaries. Poor management of this exposure can affect the value of companies in the long run. Modigliani and Miller (1958) proved no relation between the value of a company and the financing decision due to the absence of imperfect market conditions (Velasco, 2014, p. 1). In the recent past, a slew of studies have indicated that hedging can increase the firm's value if imperfections are prevalent in the capital markets. For this purpose, theories have been developed on optimal hedging. These theories explain the reasons firms may be interested in hedging. The corporate hedging theories have addressed market imperfections such as financial distress cost, underinvestment problem, agency conflicts between managers and shareholders, etc.

Most of the studies on corporate hedging are based on the usage of derivatives to hedge exchange rate risks. Very few studies have focused on other types of operational and financial hedging to manage the risk. Recent 
empirical studies have identified the usage of foreign currency debt as an important tool to hedge foreign exchange risk. Companies with export sales constituting a significant turnover portion are most likely to hedge foreign currency debt (Muff et al., 2008, p. 1). Borrowings denominated in foreign currency act as a natural hedge to a company's currency exposure in that currency. This is because companies with income in foreign currency can borrow in that currency to perform cash-flow matching and eliminate or reduce exchange rate risk (Vivel Búa, Otero González, \& Fernandez Lopez, 2009, pp. 8-9). Besides, numerous empirical studies have reported using foreign currency debt as an operational hedge and suggest that the main reason for foreign currency borrowing is to manage exchange rate risk (Bradley et al., 2002). Therefore, any studies that ignore foreign currency borrowings may be overlooking important instruments to manage exchange rate risk.

The paper is organized as follows. Section 1 provides the theoretical framework. Section 2 contains the literature review of earlier studies and their key findings. Section 3 discusses the aims/objectives of the study. Section 4 describes the methodology and data set. Section 5 considers the results. Section 6 contains a full discussion of the results and compares the results with those in the literature. The last section concludes the paper.

\section{THEORETICAL FRAMEWORK}

The theoretical framework underpinning Forex hedging practices in the corporates is summarized further.

\subsection{Financial distress}

Smith et al. (1985) found that highly levered firms with cash-flow problems or nearing bankruptcy will hedge risk to mitigate financial distress and thereby increase shareholder value (Muff et al., 2008, pp. 7-8). Hedging risk can reduce the likelihood of a firm's financial distress cost by reducing cash flow volatility. The advantage one can get by reducing this cost from risk management depends on factors such as the likelihood of encountering distress and financial distress cost. The greater the possibility of distress, the greater the benefits of hedging risks. Subsequently, researchers have employed measures to proxy for financial distress, primarily based on the borrowing capacity of the firm or leverage. The findings from Froot et al. (1993) and Smith et al. (1985) provide support to theoretical arguments that the higher the probability of financial distress, the greater is the financial derivative use (Muff et al., 2008, p. 8).

\subsection{Underinvestment}

The underinvestment problem arises when a firm cannot make capital investments due to the high cost of external financing and lack of internally generated funds. Firms reduce their capex by roughly USD 0.35 for each dollar reduction in cash flows. Thus, a highly levered firm may be forced to take up sub-optimal investment strategies and forego profitable investment opportunities - the so-called underinvestment problem. Froot et al. (1993), Smith et al. (1985), Mayers et al. (1982), Bessembinder (1991) argue that through effective risk management, the issue of underinvestment is reduced (Charumathi \& Kota, 2012, pp. 252253). This happens when the management intends to maximize its wealth at the cost of bondholders and refuses to invest in low-risk projects. The conflict between equity and bondholders arises due to cash flow variation and the high cost of external financing - this can be resolved by hedging (Charumathi \& Kota, 2012, pp. 252-253).

\subsection{Hedging substitutes}

Nance et al. (1993) and Froot et al. (1993) found that firms can mitigate the expected cost of financial distress and agency cost by maintaining a larger short-term liquidity position or by having a lower dividend pay-out (Muff et al., 2008, p. 9). Therefore, holding liquid assets will reduce financial distress. In general, holding high liquidity can be considered as a substitute for hedging activity. This is because the cost of holding liquid assets is lower than the cost of entering into financial hedging contracts.

\subsection{Size and international operations}

The relationship between firm size and the extent of using derivatives has been discussed in 
the literature and empirically tested. Studies have found that smaller firms have reported larger use of derivatives than larger firms. Smaller firms are more likely to default due to their due to less diversified nature of their assets and restricted access to external sources of capital (Charumathi \& Kota, 2012, p. 254). This observation indicates that smaller firms have a high demand for derivatives for hedging risks. Alternatively, size also reflects economies of scale, indicating a positive relationship between size and the likelihood of hedging (Charumathi \& Kota, 2012, p. 254).

\subsection{Managerial risk aversion}

The studies done earlier found evidence that hedging increases with managerial shareholding and decreases with managerial option ownership. Graham and Rogers (2002) and Dunne et al. (2004) also find that hedging increases with managerial shareholdings only (Muff et al., 2008, p. 6). These findings conclude that managerial shareholdings and stock option plans are important determinants of hedging. Smith et al. (1985) argued that managers with more wealth invested in a firm will have greater incentives to hedge the firm's risk and that managers' compensation can influence their hedging choices. Haushalter (2000) and Jalilvand (1999) found no evidence that managerial risk aversion or shareholding affect corporate hedging (Charumathi \& Kota, 2012, pp. 253-254). Ambiguity persists in analyzing the association between managerial holdings and hedging risks using derivatives.

\subsection{Description of variables}

Table 1. Variables for the study

\section{LITERATURE REVIEW}

To undertake the objectives of the study, the review of earlier studies that were associated with the topic under the study was carried out.

El-Masry et al. (2007) found that a firm's foreign operations affected the sensitivity to exchange rate exposure. Muff et al. (2007) identified variables such as low profitability and high growth opportunities as the most likely reasons companies choose currency derivatives to hedge risks. VuralYavas (2016) found variables such as firm size, foreign sales, profitability, and dividend yield, which increased the likelihood of hedging. Leverage, interest coverage had a negative impact on the likelihood of hedging. Similar findings were found in the studies by Afza and Alam (2011) and Velasco (2014). According to a study by Charumathi and Kota (2012), size was a major determinant of large Indian companies' derivative usage. Clark and Judge (2008) identified size, financial distress, and leverage as significant variables influencing companies to raise foreign currency loans.

Khan et al. (2017) provide evidence that companies with high financial distress cost, high export sales, and lower managerial holdings used derivatives to manage currency risk. Omar Bin Abdullah et al. (2017) reviewed earlier studies on the management of foreign exchange risk and found that international trade (exports and imports) results in a high level of foreign currency exposure in developed and developing economies. A survey of practicing managers was carried out by Mitra (2013). The findings indicate that corporates widely used the forward contract

\begin{tabular}{|c|c|c|c|}
\hline Variable & Predicted sign as per theory & Symbol & Proxy for \\
\hline Debt to total assets & + & DTA & Financial distress \\
\hline Debt to net worth & + & DNW & Financial distress \\
\hline Interest coverage ratio & - & $\mathrm{ICR}$ & Financial distress \\
\hline Quick ratio & - & QR & Hedging substitutes \\
\hline Log of revenue & + & $\ln R$ & Economies of scale \\
\hline Promoters holding as a $\%$ of total holding & - & $\mathrm{PH}$ & Managerial risk aversion \\
\hline Price to earnings ratio & - & PER & Underinvestment \\
\hline Interaction between $R \& D$ and $Q R$ & - & RDQR & Underinvestment \\
\hline Log of enterprise value & - & $\operatorname{lnEV}$ & Size \\
\hline Export/total sales & + & EXS & International operations \\
\hline
\end{tabular}


to hedge foreign currency risk. Very few companies used other instruments like futures, options, and swaps. Pennings (2002) analyzed the factors affecting the behavior of initiating a position in the derivatives market. The study identified the manager's risk attitude, the manager's psychological reference price as the variables in initiating a futures contract. Naghai et al. (2018) compared the hedging strategies of selected US and Indian companies and found no significant (statistically) variables in explaining the decision to hedge exchange rate risk. According to them, the findings of the study did not support any theory behind hedging by companies.

\subsection{Research gap}

There have been several studies on managing currency risk both from a global and Indian perspective. Several studies in the global context have analyzed the determinants of hedging policies and identified variables significantly influencing hedging decisions. In the Indian context, Charumathi and Kota (2012) used multiple regression approaches to determine what factors influence the dependent variable, the dependent variable being the total value of derivative contracts used by the companies under study. However, not many studies have focused on hedging exchange rate risk using foreign currency loans/borrowings. Also, the 'industry effect' has not been captured while discussing risk management in previous research. The present study is an attempt to address the gap mentioned above. Developing a logit model will be imperative in explaining the relationship between corporate hedging theories and the usage of foreign currency loans.

\section{AIMS}

The paper aims to analyze the association between corporate hedging theories and the usage of foreign currency loans. Variables describing the theories are considered independent variables, and the dependent variable is a binary variable. Motivated by the change in the financial reporting requirements (IAS21) needing all companies in India to provide details on how exchange rate risk/exposure is managed, this paper has the following objectives:
1. To examine whether the users and non-users of foreign currency loans have different firm-level characteristics and interpret the results thereof.

2. To determine whether the corporate hedging theories satisfactorily explain companies' reasons for using foreign currency loans to hedge exchange rate risk.

\section{METHODOLOGY}

The data for the present study is from secondary sources. Major sources for the secondary data include annual reports of the companies and Capital Line database. Companies selected for the study belong to S\&P CNX 500, which is India's first broad-based index. S\&P CNX 500 represents $96 \%$ of the total market capitalization in India. A sample of 349 companies was finally considered for the analysis. The sample was arrived at after excluding banking companies and those companies for which complete data was not available. The study was conducted for the year ending $31^{\text {st }}$ March, 2018 (FY 2017-2018). The number of year(s) for the present study is on similar lines as Linsley and Shrives (2006), Nguyen and Faff (2003), and Muff et al. (2008). It is to be mentioned that the number of samples considered for the present study is much higher than the samples of previous studies.

The paper includes descriptive statistics such as mean, standard deviation, skewness, and kurtosis to describe the variables used for building the model. To test the assumption of normality, Shapiro-Wilk test was employed. Based on this, a decision is made to either use the parametric test procedures or non-parametric procedures. If the normality is satisfied, t-test is employed. If not, the Mann-Whitney $U$ test is used to test the significant difference between the companies that go for FCL and those that do not go for FCL.

The study employs logistic regression to model the probability of hedging decisions against non-hedging decisions (Pennings, 2002; Whidbee \& Wohar, 1999). The dependent variable takes a binary response, wherein ' 1 ' is assigned to companies going for foreign currency loans, ' 0 ' for companies not going for foreign currency loans. The independ- 
ent variables are debt/total assets, debt/net worth, promoters holding as \% of total holdings, PE ratio, interest coverage ratio, quick ratio, $R \& D$ expenses to sales, $\ln$ (enterprise value), ln (revenue), exports to sales. Table 1 shows the theoretical relationship between the variables and the likelihood of raising foreign currency loans. The following is the logit model proposed in the study:

$$
\begin{aligned}
& \ln \left(\frac{p}{1-p}\right)=\beta_{0}+\beta_{1} X_{1}+ \\
& +\beta_{2} X_{2}+\beta_{3} X_{3}+\ldots+\beta_{k} X_{k},
\end{aligned}
$$

$\ln (p /(1-p))-\log$ odds of companies using foreign currency loans against not using foreign currency loans and $X_{1}, X_{2}, X_{3}, \ldots, X_{k}$ are the independent variables used for the study. The probability of a company going for foreign currency loans (FCL) is modeled as follows:

$$
p=\frac{1}{1+e^{-\left(\beta_{0}+\beta_{1} X_{1}+\beta_{2} X_{2}+\beta_{3} X_{3}+\ldots+\beta_{k} X_{k}\right)}} .
$$

The logistic regression estimates the parameters $\beta_{1}, \beta_{2}, \ldots, \beta_{k}$ in the model, such that the likelihood of the data used in the model is maximized. The parameters can be interpreted as the change in the log-odds associated with a one-unit change of the independent variable. $\beta_{1}$ is the change in the log-odds for a change in the category of the industry. To test the significance of the model, the study used the likelihood ratio test. Hosmer and Lemeshow test was employed for the analysis to test the goodness of fit of the logistic function. For testing the significance of the individual regression coefficients, Wald test was used.

Table 2. Descriptive statistics
The following equations will help interpret the coefficients when dummy variables for industry classification are introduced into the model with all the significant variables. The model $X_{1}$ corresponds to industry type and will be equal to 1 if the industry is manufacturing and 0 if the industry is services. $X_{2}, X_{3}, X_{4}, X_{5}$ denote the debt of net worth, interest coverage ratio, natural log of revenue, and export to sales. Equation (2) is for the services company, and equation (3) is for a manufacturing company:

$$
\begin{gathered}
\ln \left(\frac{p}{1-p}\right)=\beta_{0}+\beta_{2} X_{2}+\beta_{3} X_{3}+\ldots+\beta_{k} X_{k} \\
\ln \left(\frac{p}{1-p}\right)=\beta_{0}+\beta_{1} X_{1}+ \\
+\beta_{2} X_{2}+\beta_{3} X_{3}+\ldots+\beta_{k}
\end{gathered}
$$

The difference between equations (2) and (3) is the coefficient $\beta_{1}$, which contributes to the odds of a company in the 'Manufacturing sector' opting for foreign currency loans. The model coefficients will be interpreted concerning services and manufacturing companies going for FCL or not.

\section{RESULTS}

Table 2 provides the descriptive statistics of

\begin{tabular}{|c|c|c|c|c|c|}
\hline Variables & Mean & Std. deviation & Skewness & Kurtosis & Test for normality \\
\hline Debt to total asset & .1795 & .1650 & .8369 & .0700 & 0.0001 \\
\hline Debt to net worth & .8370 & 3.2224 & 14.4692 & 240.5993 & 0.0001 \\
\hline Interest coverage ratio & 464.4948 & 3881.0818 & 16.0736 & 278.9548 & 0.0001 \\
\hline Quick ratio & 1.4082 & 1.3994 & 4.4713 & 33.8351 & 0.0001 \\
\hline Natural log of revenue & 24.5462 & 1.2984 & .8247 & 1.2366 & 0.0001 \\
\hline Promoters holdings as $\%$ of total holdings & .5503 & .1747 & -.6813 & .6660 & 0.0001 \\
\hline PE ratio & 25.2548 & 193.4347 & -5.9048 & 92.6104 & 0.0001 \\
\hline R\&D expenses to sales & .0198 & .2130 & 18.1263 & 334.6023 & 0.0001 \\
\hline Export to sales & .1491 & .2322 & 2.3007 & 6.5781 & 0.0001 \\
\hline Natural log of EV & 25.4564 & 1.2056 & .4918 & 1.4241 & 0.0001 \\
\hline RDQR & .0303 & .3220 & 18.0368 & 332.3876 & 0.0001 \\
\hline
\end{tabular}
the variables considered for the study and results of testing for normality. On average, $18 \%$ of the total assets are in the form of borrowings for the companies under study. Debt to net worth shows the proportion of borrowed funds 
to shareholders funds, and the mean value of 0.83 indicates that the proportion of borrowed funds is high compared to shareholders funds. The interest coverage ratio (mean, 464 times) indicates that companies have adequate operating profits to honor all interest obligations. The companies' short-term solvency is more than adequate (the mean value of $1.40>1$ ). The promoters of the company hold $55 \%$ of the holdings in all the companies. The results also indicate that around $15 \%$ of the total revenue is in the form of exports, and companies spend very little money on research and development. On average, $1.98 \%$ of the revenue is spent on research and development. The results using ShapiroWilk test indicate that the variables are not normally distributed.

Table 3 shows the univariate analysis results for foreign currency loan users and non-users of foreign currency loans as groups. As indicated by the $p$-values, except for variables "promoters holdings as \% of total holdings", "PE ratio", and "RDQR", there exists a significant difference between the companies that choose FCL and those that do not choose FCL. The results indicate an association between the variables and the choice of foreign currency loans to hedge foreign exchange risks. This motivates in building a model to measure the level of influence that variables have on the chances of a company going for FCL.
Table 4. Number of companies with/without foreign currency loans

\begin{tabular}{l|c}
\multicolumn{1}{c}{ Source: Authors' classification. } \\
\hline Particulars & $\begin{array}{c}\text { No. of } \\
\text { companies }\end{array}$ \\
\hline Companies with foreign currency loans & 189 \\
\hline Companies without foreign currency loans & 160 \\
\hline Total & 349 \\
\hline
\end{tabular}

Table 4 provides the number of companies with borrowings denominated in foreign currencies and the number of companies that do not have overseas borrowings. Figure 1, showing the classification of companies, is included in the Appendix. The table shows that $55 \%$ of the companies $(189 / 349=.55 / 55 \%)$ have raised money from overseas markets for meeting financing requirements. Around $45 \%$ of the companies have not raised any money from overseas markets.

Table 5. Classification of companies - industry type

Source: Authors' classification

\begin{tabular}{l|c}
\multicolumn{1}{c|}{ Particulars } & $\begin{array}{c}\text { No. of } \\
\text { companies }\end{array}$ \\
\hline Companies under 'Manufacturing sector' & 262 \\
\hline Companies under 'Services sector' & 87 \\
\hline Total & 349 \\
\hline
\end{tabular}

Table 5 provides the number of companies falling under 'Manufacturing' and 'Services'. The table shows that $55 \%$ of the companies $(262 / 349=$ $.75 / 75 \%)$ belong to the manufacturing sector, and

Table 3. Results of univariate analysis (difference between means of users vs. non-users of foreign currency loans)

\begin{tabular}{|c|c|c|c|}
\hline Variable & Mann-Whitney U & $p$-value & Significant \\
\hline Debt to total asset & 6735 & $2.10691 \mathrm{E}-19$ & Yes \\
\hline Debt to net worth & 6971 & $2.00364 \mathrm{E}-18$ & Yes \\
\hline Interest coverage ratio & 10784 & $2.48061 \mathrm{E}-06$ & Yes \\
\hline Quick ratio & 11775 & 0.000254163 & Yes \\
\hline Natural log of revenue & 10602 & $9.44608 \mathrm{E}-07$ & Yes \\
\hline Promoters holdings as $\%$ of total holdings & 14510 & 0.449894386 & No \\
\hline PE ratio & 12877 & 0.016169163 & Yes \\
\hline$R \& D$ expenses to sales & 13936 & 0.151909153 & No \\
\hline Export to sales & 12809 & 0.01012378 & Yes \\
\hline Natural log of EV & 12523 & 0.005355783 & Yes \\
\hline RDQR & 14474 & 0.404620357 & No \\
\hline
\end{tabular}


the rest belong to the 'Services' sector. Figure 2, showing the classification of companies as manufacturing and services, is included in the Appendix.

\section{RESULTS OF THE LOGISTIC REGRESSION MODEL}

The logistic regression model was built to identify the factors that are significantly influencing the likelihood of a company going for foreign currency loans (FCL). As proposed in equation (1), the response variable is the log odds of a company going for FCL, and the model is used to predict the chances of a company going for FCL, given the information on all the variables. Table 6 gives the results of the analysis. One can note that model 1 is with all the variables considered, and model 2 with those variables significantly influencing the likelihood of a company going for foreign currency loans.

The results in Table 6 indicate that the variables quick ratio, promoters holdings as $\%$ of total holdings, $\mathrm{PE}$ ratio, natural log of EV, RDQR (interaction between R\&D expenses and quick ratio) are not significantly influencing the company's decision on choosing FCL. The rebuilt model, excluding variables that are not statistically significant, is shown in model 2.
The results in model 2 show a significant association between 'industry type' and usage of foreign currency loans. Manufacturing companies (companies in the 'Services' sector are considered a base category) are likely to raise foreign currency loans than the companies in the 'Services' sector. Based on the coefficient value, the chance of a manufacturing company raising foreign currency loans is 2.65 times higher than the companies in the other category. The paper finds that companies (manufacturing) with high borrowings (debt to net worth), export sales (export to sales), economies of scale (log of revenue) are likely to raise funds through foreign currency loans. The coefficient value of interest coverage ratio indicates that the likelihood of a company raising foreign currency loan decreases by (1-.99) $0.1 \%$.

The paper looks at the accuracy of the model built, and Table 7 provides the details.

Table 7. Confusion matrix and statistics

Source: Authors' analysis.

\begin{tabular}{l|cc}
\hline \multicolumn{1}{c|}{ Variables } & \multicolumn{2}{c}{ Reference } \\
\hline Prediction & $X_{0}$ & $X 1$ \\
\hline$X_{0}$ & 125 & 49 \\
\hline$X_{1}$ & 46 & 127 \\
\hline Accuracy: 0.7262 & & \\
\hline $95 \%$ Cl: $(0.6761,0.7725)$ & & \\
\hline Sensitivity: 0.7310 & & \\
\hline Specificity: 0.7216 & \\
\hline
\end{tabular}

Table 6. Results of logistic regression

Source: Authors' analysis.

\begin{tabular}{|c|c|c|c|c|c|c|}
\hline \multirow{2}{*}{ Model } & \multirow{2}{*}{ Variables } & \multirow{2}{*}{ B } & \multirow{2}{*}{$p$-value } & \multirow{2}{*}{$\operatorname{EXP}(B)$} & \multicolumn{2}{|c|}{ 95\% C.I. for EXP(B) } \\
\hline & & & & & Lower & Upper \\
\hline \multirow{11}{*}{ Model 1} & Intercept & -7.8865 & 0.0072 & 0.0004 & 0.0000 & 0.1179 \\
\hline & Debt to net worth & 1.1007 & $0.0000^{*}$ & 3.0063 & 1.7672 & 5.1142 \\
\hline & Interest coverage ratio & -0.0008 & 0.0793 & 0.9992 & 0.9983 & 1.0001 \\
\hline & Quick ratio & -0.0496 & 0.6433 & 0.9516 & 1.1640 & 2.2627 \\
\hline & Natural log of revenue & 0.4842 & $0.0043^{*}$ & 1.6229 & 3.6405 & 46.8612 \\
\hline & Promoters holdings as $\%$ of total holdings & 0.8743 & $0.2400^{*}$ & 2.3971 & 0.7713 & 1.1740 \\
\hline & PE ratio & -0.0014 & 0.3855 & 0.9986 & 0.9955 & 1.0017 \\
\hline & Export to sales & 2.5697 & $0.0001^{*}$ & 13.0614 & 0.5576 & 10.3051 \\
\hline & Natural log of EV & -0.2321 & 0.1568 & 0.7929 & 0.5750 & 1.0933 \\
\hline & RDQR & -3.1322 & 0.2984 & 0.0436 & 0.0001 & 15.9872 \\
\hline & Industry type & 1.0193 & $0.0011^{*}$ & 2.7711 & 1.5019 & 5.1128 \\
\hline \multirow{6}{*}{ Model 2} & Intercept & -9.2388 & 0.0003 & 0.0001 & 0.0000 & 0.0149 \\
\hline & Industry type & 0.9773 & $0.0012 *$ & 2.6571 & 1.4686 & 4.8077 \\
\hline & Debt to net worth & 1.2227 & $0.0000^{*}$ & 3.3963 & 2.0143 & 5.7265 \\
\hline & Interest coverage ratio & -0.0008 & $0.0597 *$ & 0.9992 & 0.9985 & 1.0000 \\
\hline & Natural log of revenue & 0.3132 & $0.0028 *$ & 1.3678 & 1.1136 & 1.6801 \\
\hline & Export to sales & 2.1743 & $0.0003^{*}$ & 8.7964 & 2.7034 & 28.6218 \\
\hline
\end{tabular}


Table 7 indicates that the model has the desired levels of accuracy. The overall accuracy of the model is $73 \%$, which means $73 \%$ of the model's prediction is correct (either going for FCL or not going for FCL). Sensitivity of $73 \%$ shows that firms that raise foreign currency loans are correctly classified as users of foreign currency loans. Specificity of $72 \%$ shows that companies that do not raise foreign currency loans are classified as non-users of foreign currency loans. It is interesting to note that both the levels are above $70 \%$ and reflect the quality of the model in classifying the companies correctly.

From the likelihood ratio test (Chi-squared (5) = 97.3304 [0.0000]), the study infers that the model is significant. Also, Hosmer and Lemeshow goodness of fit (GOF) test $(X$-squared $=2.299, \mathrm{df}=8$, $p$-value $=0.9704)$ indicates that the logistic model is a good fit for the data considered.

\section{DISCUSSION}

The study found that around 55\% of the sample companies have raised foreign currency loans to hedge risks. As shown in Table 2, the descriptive statistics indicate that the sample companies were highly levered and maintained adequate liquidity to meet their short-term obligations. The companies also had adequate operating profits to honor all interest obligations, and a very small portion of the revenue was spent on research and development. The results of the univariate analysis indicate that values of 'users of foreign currency loans' for variables such as debt/net worth, log of revenue, export/total sales, interest coverage ratio, quick ratio, PE ratio were significant from 'non-users of foreign currency loans'.

The study found that companies in the 'manufacturing sector' were more likely to raise foreign currency loans than the companies in the 'Services sector'. Therefore, 'industry type' was significantly associated with the likelihood of companies raising loans in foreign currency. The variable debt to net worth was positively associated with the likelihood of companies borrowing in foreign currency. This indicates companies with high borrowings are likely to raise loans in foreign denominated currencies. The findings are consistent with the results of Keloharju and Niskanen (2001), Aabo (2006), and Clark and Judge (2008). Keloharju and Niskanen (2001) established the relationship between the debt level and the company's volume of foreign currency loan. The findings of Aabo (2006) indicate that if a company has a predisposition to use debt, it can be assumed to have a predisposition to use foreign debt. The findings also emphasize that companies with high borrowings locally raise foreign currency loans for refinancing their existing loans and take advantage of interest rate differentials between the local currency and foreign currency.

The variable $\ln R$ (natural log of revenue) was positively associated with the likelihood of companies raising foreign currency loans. Thus, economies of scale are a significant variable that determines the hedging activities. The results corroborate with the findings of Aabo (2006) that foreign currency loan raising can be an expensive hedging option for smaller companies. Companies with export sales (measured by export/sales) were also found to be significantly associated with the likelihood of raising foreign currency loans. The issue of foreign currency loans can act as a natural hedging instrument for companies with foreign income. In this case, the flow of liabilities meant for repayment of the principal and interest of the foreign currency loans would be compensated by income in that currency generated by foreign operations (Vivel Búa et al., 2009). Allayannis and Ofek (2001) found that companies with greater foreign currency exposure were most likely to use foreign debt. Interest coverage ratio was negatively associated with the likelihood of raising foreign currency loan/debt. It indicates that companies with high operating profits concerning the annual finance costs were less likely to raise foreign currency loans.

Based on the results, the study provides directions for future research, and they are as follows:

1. The present study has used debt/net worth as a proxy to financial distress to analyze its association with the likelihood of companies raising foreign currency loans. Additional variables such as credit rating, payback capacity, etc., and interaction between these variables will add new dimensions to the study. 
2. Future studies can focus on tax aspects, especially with countries having a progressive tax system. Managing risks through foreign currency loans may reduce the expected tax payments.

3. Future studies can also classify the industry type' into specific sectors to explore the asso- ciation with hedging foreign exchange risks for specialized sectors.

4. A longitudinal study in the form of panel data may be considered for future research to account for other control variables, which probably may explain the reasons for the usage of foreign currency loans.

\section{CONCLUSION}

The study concludes that theories such as financial distress, size, and extent of international operations explain the likelihood of companies raising foreign currency loans to hedge exchange rate risks. The present study's uniqueness is that it could establish an alternate technique for hedging risks apart from using financial derivatives in the Indian context. Foreign currency loans could be used as an alternative or in tandem with derivatives to hedge operational risks. Foreign currency loans help companies to refinance their loans borrowed in the local currency. This aspect connects well with the present scenario wherein most of the companies have borrowed in the local currency. FCL helps companies to repay their existing loans in the local currency and allows them the benefit of reduced interest on borrowings as the interest rates are much lower for the FCL when compared to the domestic borrowings. Companies with economies of scale and foreign currency exposure (export sales) may consider taking out foreign currency loans to hedge operational risks. The study has implications for the practitioners as they understand the variables which may encourage companies to raise foreign currency loans and the type of industries that borrowed/may borrow foreign currency loans from overseas markets.

\section{AUTHOR CONTRIBUTIONS}

Conceptualization: Mahadevan Sriram.

Data curation: Mahadevan Sriram.

Formal analysis: Srilakshminarayana Gali.

Funding acquisition: Srilakshminarayana Gali.

Investigation: Mahadevan Sriram.

Methodology: Srilakshminarayana Gali.

Project administration: Mahadevan Sriram.

Software: Srilakshminarayana Gali.

Supervision: Srilakshminarayana Gali.

Validation: Mahadevan Sriram.

Writing - original draft: Mahadevan Sriram.

Writing - review \& editing: Mahadevan Sriram.

\section{REFERENCES}

1. Aabo, T. (2006). The importance of corporate foreign debt as an alternative to currency derivatives in actual management of exchange rate exposures. European Financial Management, 12(4), 633-649.

Retrieved from https://papers.ssrn. com/sol3/papers.cfm?abstract_ $\mathrm{id}=467422$
2. Afza, T., \& Alam, A. (2011) Determinants of corporate hedging policies: A case of foreign exchange and interest rate derivative usage. African Journal of Business Management, 5(14), 572-579. Retrieved from https://www.researchgate.net/
publication/233842308_Determinants_of_corporate_hedging_ policies_A_case_of_foreign_exchange_and_interest_rate_derivative_usage

3. Allayannis, G., \& Ofek, E. (2001). Exchange rate exposure, hedging, and the use of foreign currency 
derivatives. Journal of International Money and Finance, 20, 273-296. https://doi.org/10.1016/S02615606(00)00050-4

4. Bessembinder, H. (1991). Forward contracts and firm value: Investment incentive and contracting effects. Journal of Financial and Quantitative Analysis, (December), 519-532. Retrieved from https://www.jstor. org $/$ stable $/ 2331409$ ?seq $=1$

5. Bradley, K., \& Moles, P. (2002). Managing strategic exchange rate exposures: evidence from UK firms. Managerial Finance, 28(11), 28-42. https://doi. org/10.1108/03074350210768149

6. Charumathi, B., \& Kota, H. B. (2012). On the Determinants of Derivative Usage by Large Indian Non-financial Firms. Global Business Review, 13(2), 251-267. Retrieved from https://www.researchgate.net/ publication/254092100_On_ the_Determinants_of_Derivative_Usage_by_Large_Indian_ Non-financial_Firms

7. Clark, E., \& Judge, A. P. (2008). The Determinants of Foreign Currency Hedging: Does Foreign Currency Debt Induce a Bias? European Financial Management, 14(3), 445-469. https://doi. org/10.1142/9789813224940_0018

8. Dunne, T. M., Helliar, C., Power, D., Mallin, C. A., Ow-Yong, K. H., \& Moir, L. (2004). The introduction of Derivatives Reporting in the UK: A Content Analysis of FRS13 Disclosures. Journal of Derivatives Accounting, 1(2), 205-219. Retrieved from https://www.worldscientific.com/ doi/10.1142/S0219868104000166

9. El-Masry, A., Abdel-Salam, O., \& Alatraby, A. (2007). The Exchange rate exposure of U.K. nonfinancial companies. Managerial Finance, 33(9), 620-641. Retrieved from https://www.researchgate.net/ publication/40498395_The_Exchange_Rate_Exposure_of_UK_ Non-financial_Companies

10. Froot, K., Scharfstein, D., \& Stein, J. (1993). Risk Management:
Coordinating corporate investment and financing policies. Journal of Finance, 48, 16291658. https://www.jstor.org/ stable $/ 2329062$ ?seq $=1$

11. Graham, J. R., \& Rogers, D. A. (2002). Do Firms hedge in response to tax incentives? Journal of Finance, 57(2), 815-839. https:// faculty.fuqua.duke.edu/ jgraham/ website/TaxHedgingJF.pdf

12. Haushalter, G. D. (2000). Financing policy, basis risk, and corporate hedging: Evidence from oil and gas producers. The Journal of Finance, 55(1), 107-151. https:// www.jstor.org/stable/222552?seq=1

13. Jalilvand, A. (1999). Why firms use derivatives: Evidence from Canada. Canadian Journal of Administrative Sciences, 16(3), 213-228.

14. Keloharju, M., \& Niskanen, M. (2001). Why do firms raise foreign currency denominated debt? Evidence from Finland. European Financial Management, 7, 481496. Retrieved from https://www. aalto.fi/sites/g/files/flghsv161/ files/2018-12/foreign_currency_ denominated_debt.pdf

15. Khan, N., Ali, K., Kiran, A., Mubeen, R., Khan, Z. N., \& Ali, N. (2017). Factors that Affect the Derivatives Usage of Non-Financial Listed Firms of Pakistan to Hedge Foreign Exchange Exposure. Retrieved from https://www.researchgate. net/publication/311015865_Factors_that_Affect_the_Derivatives_ Usage_of_Non-Financial_Listed_ Firms_of_Pakistan_to_Hedge_ Foreign_Exchange_Exposure

16. Linsley, M. P., \& Shrives, J. P. (2006). Risk reporting: A study of risk disclosures in the annual report of UK companies. The British Accounting Review, 38(4), 387-404.

17. Mayers, D., \& Smith, C. W. Jr. (1982). On the corporate demand for insurance. Journal of Business, 55(2), 281-296. Retrieved from https://www.jstor.org/ stable $/ 2352704$ ? seq $=1$

18. Mitra, A. (2013). Comparative Analysis of Foreign Exchange Risk Management Practices among
Non Banking Companies in India. Africa Development and Resources Research Institute (ADRRI) Journal, 3(3), 38-51. Retrieved from https:// www.academia.edu/5302230/ Comparative_Analysis_of_Foreign_Exchange_Risk_Management_Practices_among_Non_ Banking_Companies_in_India

19. Modigliani, F., \& Miller, M. H. (1958). The Cost of Capital, Corporation Finance and the Theory of Investment. American Economic Review, 48, 261-297. Retrieved from https://gvpesquisa. fgv.br/sites/gvpesquisa.fgv.br/files/ arquivos/terra_-_the_cost_of_capital_corporation_finance.pdf

20. Muff, T., Diacon, S., \& Woods, M. (2008). The Management of Currency Risk: Evidence from UK Company Disclosures (Discussion Paper Series). Centre for Risk and Insurance Studies, Nottingham University Business School. Retrieved from https:// www.semanticscholar.org/paper/ The-Management-of-CurrencyRisk\%3A-Evidence-from-UKMuff-Diacon/8df62838eeff83bf619 d18d354007989d2ee8958

21. Naghai, M., Nagahisarchoghaei, M., Solieman, N., \& Raed, J. M. (2018). Hedging Strategies of Corporate Houses. Journal of Business Administration Research, 7(1), 6-19. https://doi.org/10.5430/ jbar.v7n1p6

22. Nance, D. R., Smith, C. W., \& Smithson, C. W. (1993). On the determinants of corporate hedging. Journal of Finance, (March), 267284. Retrieved from https://www. jstor.org/stable/2328889

23. Nguyen, H., \& Faff, R. (2003). Can the use of foreign currency derivatives explain variations in foreign exchange exposure? Evidence from Australian Companies. Journal of Multinational Financial Management, 13(3), 193-215. https://doi.org/10.1016/S1042444X(02)00051-8

24. Omar, B., Abdullah, Nisham Kamarun, \& Mohammad Taufil (2017). Exposure of foreign Exchange risk- A Review of 
Empirical Evidences. Journal of Insurance and Financial Management, 2(5), 79-91.

25. Pennings, J. M. (2002). Pulling the Trigger or Not: Factors Affecting Behavior of Initiating a Position in Derivatives Markets. Journal of Economic Psychology, 23(2), 263-278. https://doi.org/10.1016/ S0167-4870(02)00067-3

26. Raghavendra, R. H., \& Velmurugan, P. S. (2014). The Determinants of Currency Hedging in Retrieved from Indian IT Firms. Journal of Business and Financial Affairs, 3, 125-134. Retrieved from https:// www.hilarispublisher.com/ open-access/the-determinants-ofcurrency-hedging-in-indian-itfirms-2167-0234.1000125.pdf
27. Smith, C. W., \& Stulz, R. M. (1985). The determinants of firms' hedging policies. Journal of Financial and Quantitative Analysis, (December), 391-405

28. Tufano, P. (1996). Who manages risk? An empirical examination of risk management practices in the gold mining industry. The Journal of Finance, 51, 1097-1137. Retrieved from https://erm.ncsu. edu/library/research-report/manages-risk-empirical-examination

29. Velasco, L. G. (2014). Factors Influencing derivatives usage of Companies in Philippines. Philippine Management Review, 21(1), 1-12.

30. Vivel Búa, M., Otero González, L., \& Fernandez Lopez, S. (2009).
Corporate Hedging Theories and Foreign Currency Debt: A Review of the Evidence. http://dx.doi. org/10.2139/ssrn.1523125

31. Vural-Yavas, C. (2016). Determinants of Corporate Hedging-Evidence from Emerging Markets. International Journal of Economics and Finance, 8(12), 151-162. Retrieved from https:// www.researchgate.net/publication/310751311_Determinants_ of_Corporate_Hedging_Evidence_ from_Emerging_Market

32. Whidbee, A. D., \& Wohar, M. (1999). Derivative activities and managerial incentives in the banking industry. Journal of Corporate Finance, 5, 251-276. https://doi.org/10.1016/S09291199(99)00005-X

\section{APPENDIX}

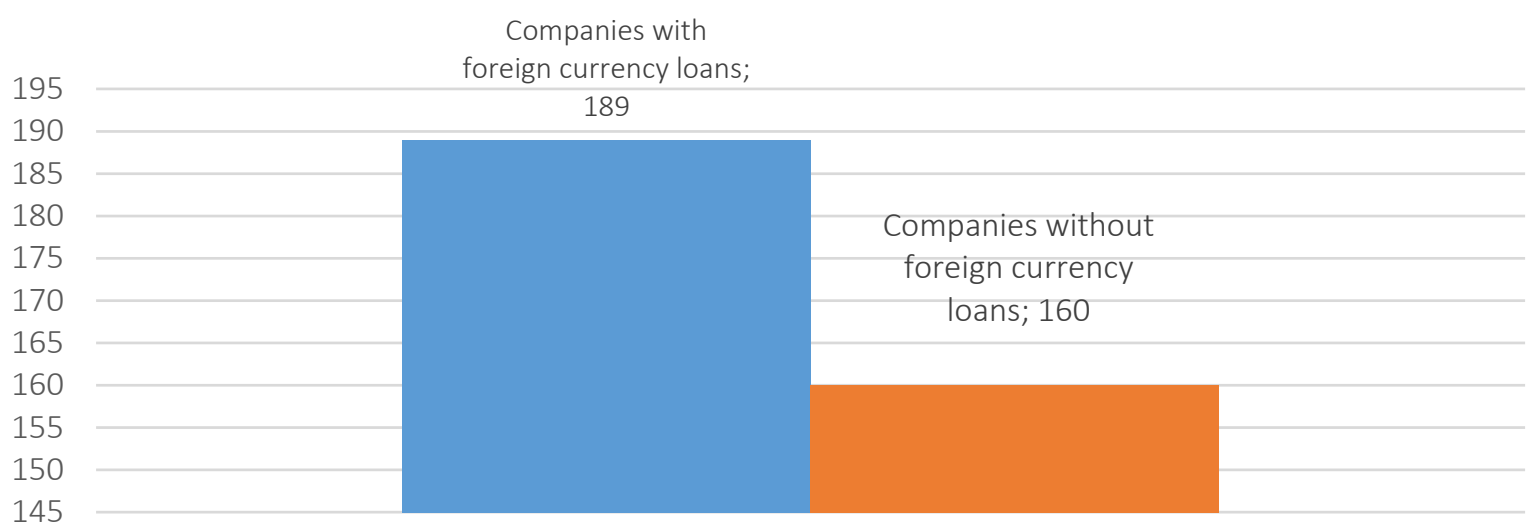

1

Figure 1. No. of companies with/without foreign currency loans

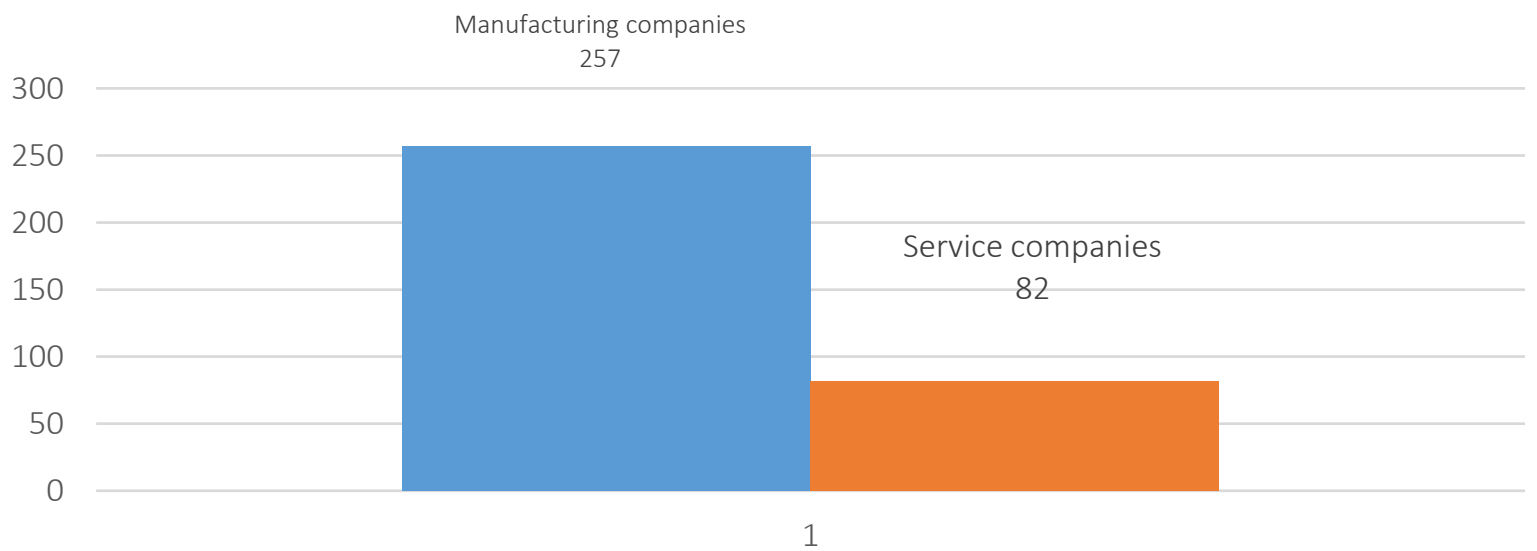

Figure 2. Classification of companies - industry type 